\title{
A framework for incorporating the prevention of Lyme disease transmission into the landscape planning and design process
}

\author{
Sarah E. Ward, Robert D. Brown
}

NOTICE: This is the authors' version of a work that was accepted for publication in LANDSCAPE AND URBAN PLANNING. Changes resulting from the publishing process, such as peer review, editing, corrections, structural formatting, and other quality control mechanisms, may not be reflected in this document. Changes may have been made to this work since it was submitted for publication. A definitive version was subsequently published in LANDSCAPE AND URBAN PLANNING, VOLUME 66, PAGE 91-106, 2004, DOI:10.1016/S01692046(03)00097-5. If you refer to this work please cite the published version. 


\begin{abstract}
A study was undertaken to investigate whether appropriate environmental planning and design techniques have the potential to reduce Lyme disease transmission in the landscape. The ecology of infectious diseases, using Lyme disease as a case study, was investigated to determine critical interactions between infectious disease and humans in the landscape. Knowledge of the life cycle of the disease's hosts revealed the critical times and places where interactions, and possible infections of humans, are most likely to occur. This information was incorporated into a decision tree framework and a landscape features checklist that will allow landscape planners and designers to determine approaches that will minimize the risk of infection in humans. A series of planning, design, and management guidelines were developed, and their application should assist in lowering the likelihood of humans contracting Lyme disease in the landscape.
\end{abstract}




\section{Introduction}

The interrelationship between human health and the natural environment has long been noted. In the medical fields, a holistic view of the patient that included environmental factors was characteristic of the methods of Hippocrates (ca. 400 BCE) and his followers (Lyons and Petrucelli, 1987). Early designers were also aware of the association between environment and health. For example, Roman architect Vitruvius (ca. $100 \mathrm{BCE}$ ) recommended not building near marshy areas. It is now understood that many pathogens causing serious illness are transmitted by mosquitoes, which have aquatic larvae and therefore breed near bodies of water.

Two developments related to health and the environment occurred near the end of the $18^{\text {th }}$ century: the advent of medical geography and the introduction of the germ theory of disease (Meade et al., 1988; McMichael, 1993). Medical geographers studied issues of human health on a regional or landscape scale. They were among the first to associate disease with geographical localities and landscape features, using maps upon which they plotted instances of disease in order to observe patterns of occurrence. Meanwhile, germ theory revolutionized the practice of western medicine, paving the way for a new biomedical view of health that relied on disinfection, vaccination, and curative drug therapies (McMichael, 1993). The increasing specialization that came with rapid advancements in medical understanding led to a philosophical approach to health that was centred on curing the disease. This view continued well into the 20th century as great scientific advancements continued to be made, including the advent of antibiotics and effective pesticides. Both of these were used extensively to combat infectious diseases, initially with almost universal success. By the second half of the 20th century problems such as antibiotic resistance were beginning to appear. In response to these challenges, scientists began to investigate novel ways of controlling the spread of disease, including investigations into the ecology of the infecting organisms (Dubos, 1965).

Throughout history, infectious diseases have been responsible for a large proportion of human suffering and mortality. At present, infectious diseases are responsible for at least $37 \%$ of deaths worldwide (Real, 1996). This figure probably underestimates actual mortality, as many deaths are attributed to secondary causes brought on by infectious diseases (Platt, 1996). While infectious diseases are often thought of as problems that are limited to developing nations, deaths due to infectious diseases increased by 58\% in the United States between 1980 and 1992 (Pinner et al., 1996).

The impact of infectious diseases on human health is underscored by the emergence of new infectious disease threats such as Lyme disease. Lyme disease (a tick-borne bacterial infection) occurs throughout most of the northern hemisphere (see Fig. 1) being transmitted by a different vector in each geographical area. In the last two decades Lyme disease has emerged as an important infectious disease in North America.

Lyme disease is the most commonly reported arthropod-borne disease in the US (Barbour and Fish, 1993), accounting for $95 \%$ of all reported vector-borne illness. In the US, a total of 16,273 cases of Lyme disease were reported to the Centers for Disease Control (CDC) in 1999 (National Center for Infectious Diseases, 1999). The disease is prevalent throughout the eastern seaboard of the US and is endemic to parts of the Midwest, the west coasts of the US and Canada, and the southernmost regions of Ontario (e.g. Long Point). The range of the tick vector, and as a consequence Lyme disease, is expanding (Anderson et al., 1990). Residents of endemic areas often exhibit a high degree of anxiety concerning the possibility of contracting Lyme disease and fear of the disease has resulted in a decrease in the use of parks and recreation areas in affected regions (Barbour and Fish, 1993). Although Lyme disease is rarely fatal, it can cause varying degrees of disability in infected individuals. The immediacy of concerns related to Lyme disease, and the connection with landscape architecture, make Lyme disease an appropriate example for this study. 


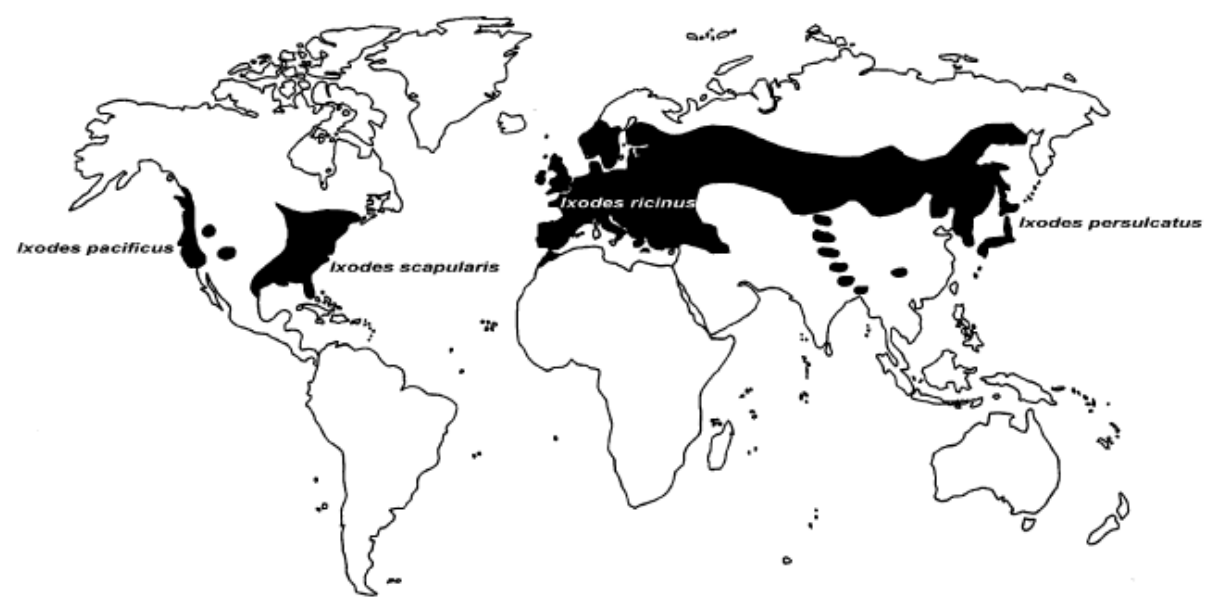

Fig. 1. Distribution of Lyme disease vectors.

Any alteration of the environment, whether natural or as a result of human activity, has the potential to impact the transmission of infectious diseases such as Lyme disease. Landscape development alters ecosystems, and therefore disrupts the balance between pathogens and their hosts, often favouring the outbreak of disease (Platt, 1996; WHO, 1980; Lederberg et al., 1992; Walsh et al., 1993; Dobson and Carper, 1996). A large number of infectious diseases have been associated with some type of environmental disturbance. Some of the best-known diseases, and the environmental factors with which they are associated, are listed in Table 1.

Vector-borne infectious diseases (i.e. those transmitted indirectly by organisms such as insects) and those associated with water are most directly connected with environmental management. This work focuses on Lyme disease, a vector-borne disease, but it should be noted that there is also tremendous potential for landscape architecture to have a positive impact on water-borne infectious diseases worldwide.

Vector control is one of the main techniques for reducing the incidence of serious vector-borne diseases. Vector control can be achieved in a number of ways, including the area-application of pesticides, behavioural modification on the part of humans in affected areas (e.g. the wearing of protective clothing, or avoidance of high-risk areas), and the use of vaccines, biological control, and environmental management. Due to concerns about the safety of widespread use of pesticides, and the inefficacy of behavioural modification and vaccine use, environmental management can provide a preferred method of vector control. Environmental management can involve a number of different types of environmental modification and manipulation (Table 2).

It is becoming increasingly clear that environmental management through appropriate planning and design, when used in concert with other control measures, can be an integral component of strategies aimed at reducing the prevalence of infectious diseases (WHO, 1980). Nobel laureate J. Lederberg (Lederberg et al., 1992) has stated that "environmental changes probably account for most emerging diseases" (p. 42). Further, he attributes the emergence of these new disease threats to environmental factors such as economic development and the associated changes in land use patterns. The US Public Health Service (1994) ascribes the emergence of many infectious diseases to "changing ecological conditions that increase (human) exposure to insect vectors, animal reservoirs, or environmental sources of novel pathogens" (p. 7). As an example, climate change has been identified as a major factor influencing the emergence or re-emergence of infectious diseases such as babesiosis, cholera, Lyme disease, typhus, malaria, yellow fever, and dengue fever. These and other vector-borne diseases are affected by changes in rainfall, temperature, and other weather variables that can alter the viability or reproductive success of the vector (Gubler et al., 2001). 
There is widespread recognition in the design professions that landscapes influence psychological health (Gerlach-Spriggs et al., 1998). In addition, there is a growing awareness of the adverse effects that air-borne pollutants, poor air circulation in buildings, and the presence of heavy metals (Bridges, 1989) and other toxins in the environment can have on human health. However, landscape architects in general have not yet included the landscape's influence on disease transmission as a major part of their planning and design process, despite the profession's integral role in the modification and manipulation of the environment. One of the few direct references to physical health and landscape architecture was made more than 30 years ago by McHarg (1969) when he referred to the importance of including measures of physical health, along with measures of social and mental health, when evaluating environments.

The growing awareness of the effect of landscape characteristics on infectious disease transmission has led to this investigation into whether appropriate environmental design has the potential to influence the level of Lyme disease transmission in humans. Lyme disease was selected as a case study because of the recent emergence of this disease in North America and because of the demonstrable relationship between Lyme disease incidence and landscape features. The approach to this study was that of integrating and applying previous research, with the goal of developing a framework for the integration of Lyme disease prevention measures into the landscape planning and design process. In order to achieve this goal, the ecology of Lyme disease was investigated and a checklist of landscape features related to Lyme disease transmission was compiled. In addition, a generic decision tree was developed to be used as a tool by decision makers in the planning and design process. A long-term goal of this project was to expand the use of the decision tree to incorporate other infectious diseases influenced by landscape characteristics. The development of a generic decision tree thereby allowed for the flexibility to apply this approach to other diseases. When combined with a landscape features checklist specific to Lyme disease ecology, the generic decision tree was made applicable to the problem of Lyme disease.

\begin{tabular}{|c|c|c|c|c|c|}
\hline Disease & Meuns of transuission & Endemic areas & Causal organism & Contributing factors & References \\
\hline$\overline{\text { Babesiosis }}$ & $\begin{array}{l}\text { Vector-bome; hard-bodied } \\
\text { ticks (Erodidae) }\end{array}$ & Worláwide & Babesia microti & $\begin{array}{l}\text { Climate change and associated changes in } \\
\text { disease hostrector habitat, reforestation, } \\
\text { changes in outdoor recreation pattems }\end{array}$ & Lederberg of al. (1992) \\
\hline Beaver fever/Giardiasis & Water-borne & $\begin{array}{l}\text { Worldiwide, more prevalent in } \\
\text { warm climotes }\end{array}$ & Giardia lambilia & Insppropriate water treatnent & Lederberg et al. (1992); Pimentel et al. (1998) \\
\hline Chagas disease & $\begin{array}{l}\text { Vector-bome: Reaturidae } \\
\text { bugs }\end{array}$ & $\begin{array}{l}\text { Primurily Central and South } \\
\text { America (estends into extremse } \\
\text { southem US) }\end{array}$ & Typanosoma criei & $\begin{array}{l}\text { Deforestation poorly constructed housing. } \\
\text { sanitation and garbage disposal practices }\end{array}$ & Walsh et al. (1993) \\
\hline Cholen & Water-bome & Worldwide & Vibrio choierae & $\begin{array}{l}\text { Climate change and associated changes in } \\
\text { disease hostvector habitat, inappropriate } \\
\text { water treatment, poor saritation }\end{array}$ & $\begin{array}{l}\text { Lederberg of al. (1992); Coiwell (1996); } \\
\text { Armelagos (1998) }\end{array}$ \\
\hline Dengue fever & $\begin{array}{l}\text { Vector-bome; mosquitoes } \\
\text { (Ades aegypt) }\end{array}$ & $\begin{array}{l}\text { Worldwide throughout tropics } \\
\text { and sub-tropics }\end{array}$ & Viral, Fiaviviridae & $\begin{array}{l}\text { Poor waste manngement, urbunization, } \\
\text { changes in land use, climate change and } \\
\text { associated changes in disease hostivector } \\
\text { habitat }\end{array}$ & Lederberg of al. (1992) \\
\hline Hantaviruses & Vector-bome; rodents & Worldwide & Viral; Bunyaniridae & Human encroachment into host habitat & Lederberg ef al. (1992); Armelagos (1998) \\
\hline $\begin{array}{l}\text { Japanese Encephalitis/St. } \\
\text { Louis Encephalitis/ } \\
\text { West Nile virus }\end{array}$ & $\begin{array}{l}\text { Vector-borme; mosquitoes } \\
\text { (Culex spp.) }\end{array}$ & Worldwide & Viral, Fianiviridae & Changing agricultural practices & Lederberg ef al. (1992); Platt (1996) \\
\hline Lassa fever & $\begin{array}{l}\text { Vector-borme; rodents of the } \\
\text { genus Mastomys }\end{array}$ & West Afica south of the Sahara & Viral, Arenaviridae & Urbarization, rodent infestation & Lederberg of al. (1992) \\
\hline Leishmaniasis & $\begin{array}{l}\text { Vector-bome; plebotomine } \\
\text { sandfly }\end{array}$ & $\begin{array}{l}\text { Asia, Africa, Mediterranean, } \\
\text { Central and South America, } \\
\text { Texsas }\end{array}$ & Leishmania spp. & Deforestation, development projects & Walsh et al (1993) \\
\hline Lyme disease & $\begin{array}{l}\text { Vector-borne; hard-bodied } \\
\text { ticks (Jrodidae) }\end{array}$ & North America, Europe, Asia & B. burgdarferi & $\begin{array}{l}\text { Suburban development, changes in land } \\
\text { use, reforestation, climate change and } \\
\text { associated changes in disease hostvector } \\
\text { habitat }\end{array}$ & $\begin{array}{l}\text { Lederberg ef al. (1992); Platt (1996); Armelagos } \\
\text { (1998); Pimentel et al. (1998) }\end{array}$ \\
\hline Malaria & $\begin{array}{l}\text { Vector-bome; mosquitoes } \\
\text { (Anophieics spp.) }\end{array}$ & $\begin{array}{l}\text { Worlatwide, particalariy in } \\
\text { tropics and sub-tropics }\end{array}$ & Plasmodium spp. & $\begin{array}{l}\text { Climate change and associated changes in } \\
\text { disease hostvector habitat, development } \\
\text { projects, deforestation, changes in land use }\end{array}$ & $\begin{array}{l}\text { Walsh et al (1993); Olinino et al (1996); Platt } \\
\text { (1996); Armelagos (1998); Pimentel et al (1998) }\end{array}$ \\
\hline $\begin{array}{l}\text { Onchocerciasis River } \\
\text { blindness }\end{array}$ & $\begin{array}{l}\text { Vector-bome; blackfly } \\
\text { (Simwitium spp.) }\end{array}$ & $\begin{array}{l}\text { Africa, Central and South } \\
\text { America, Middle East }\end{array}$ & Onchocerca voluilus & Reforestation, development & Walsh et al (1993) \\
\hline Rift valley fever & $\begin{array}{l}\text { Vector-borme; primanily } \\
\text { mosquitoes (Andes spp.) and } \\
\text { other blood-sucking insects }\end{array}$ & Africa & Viral; Buryenviridane & Development projects (dams, irrigation) & $\begin{array}{l}\text { Lederberg ef al. (1992); Platt (1996); Annelagos } \\
\text { (1998) }\end{array}$ \\
\hline Schistosomiasis Bilharzia & Vector-bome; aquatic snoils & $\begin{array}{l}\text { South America, Africa, Middle } \\
\text { East, Fur East }\end{array}$ & Schistosama spp. & $\begin{array}{l}\text { Deforestation, urbanization, changes in } \\
\text { land use, dam and road building. } \\
\text { sanitation and garbage disposal practices }\end{array}$ & $\begin{array}{l}\text { Walsh et al (1993); Platt (1996); Armelagos } \\
\text { (1998); Pimentel et al (1998) }\end{array}$ \\
\hline Yellow fever & $\begin{array}{l}\text { Vector-borne; primarily } \\
\text { mosquitoes (Adedes spp.) and } \\
\text { other blood-sucking insects }\end{array}$ & South America, Central Africa & Vural, Fiaviviridace & $\begin{array}{l}\text { Deforestation, urbanization, changes in } \\
\text { land use, climate change and associated } \\
\text { changes in disease host vector habitat }\end{array}$ & Lederberg ef al. (1992); Platt (1996) \\
\hline
\end{tabular}


Table 2

Approaches to environmental management for vector control techniques for various infectious diseases (adapted from WHO Expert Committee, 1980)

\begin{tabular}{|c|c|c|c|c|c|c|c|c|c|c|c|c|c|c|c|c|c|c|}
\hline $\begin{array}{l}\text { Voctor or } \\
\text { intermodi- } \\
\text { ato host }\end{array}$ & $\begin{array}{l}\text { Disensos } \\
\text { tansmittod }\end{array}$ & Drainage & $\begin{array}{l}\text { Total } \\
\text { oarth } \\
\text { filling }\end{array}$ & $\begin{array}{l}\text { Doepening } \\
\text { and flling }\end{array}$ & $\begin{array}{l}\text { Land } \\
\text { grading }\end{array}$ & $\begin{array}{l}\text { Volocity } \\
\text { altontion }\end{array}$ & Impoundment & $\begin{array}{l}\text { Tomrostial } \\
\text { vogetation } \\
\text { control }\end{array}$ & $\begin{array}{l}\text { Shading } \\
\text { or } \\
\text { exposure } \\
\text { to surlight }\end{array}$ & $\begin{array}{l}\text { Water lovel } \\
\text { fluctartion }\end{array}$ & $\begin{array}{l}\text { Stwicing } \\
\text { for } \\
\text { flubing }\end{array}$ & $\begin{array}{l}\text { Aquatic } \\
\text { vogotation } \\
\text { control }\end{array}$ & $\begin{array}{l}\text { Salinity } \\
\text { rogulation }\end{array}$ & $\begin{array}{l}\text { Watar } \\
\text { "wpply } \\
\text { and } \\
\text { sewerage }\end{array}$ & $\begin{array}{l}\text { Scrosuing } \\
\text { and } \\
\text { bedents }\end{array}$ & $\begin{array}{l}\text { Refuse } \\
\text { collection } \\
\text { and } \\
\text { disponsl }\end{array}$ & $\begin{array}{l}\text { Lend was } \\
\text { rostriction }\end{array}$ & $\begin{array}{l}\text { Improvod } \\
\text { housing }\end{array}$ \\
\hline $\begin{array}{l}\text { Amopheles } \\
\text { morgutoes }\end{array}$ & Malnria & *4 & $*$ & $\omega$ & $*$ & + & & $\cdot$ & + & + & + & $\cdot$ & 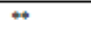 & $\cdot$ & + & + & + & $\cdot$ \\
\hline Aquatic savils & Schistosomiasis & - & + & $\leftrightarrow$ & - & - & & & & - & - & - & - & $\Leftrightarrow$ & & & - & \\
\hline $\begin{array}{l}\text { Culex and Aedes } \\
\text { mosquitoes }\end{array}$ & $\begin{array}{l}\text { Filariasis, viral, } \\
\text { and otber } \\
\text { disonen }\end{array}$ & $*$ & - & - & - & + & & - & - & - & - & - & - & - & • & * & - & - \\
\hline Blacheflies: & Oxchocarciasis & & & & & - & $*$ & & & & - & & & - & & & - & \\
\hline Homeffion & Infantile dianthoos & & & & & & & & & & & & & $\leftrightarrow$ & - & $*$ & & - \\
\hline Tratie flies & $\begin{array}{l}\text { African } \\
\text { typuosomiasis }\end{array}$ & & & & & & & 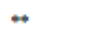 & & & & & & & & & * & \\
\hline Triatomid bugs: & Chagas disoase & & & & & & & - & & & & & & & - & & & $\leftrightarrow$ \\
\hline Rat flass & Plague & & & & & & & & & & & & & & & $*$ & & $\rightarrow$ \\
\hline Cyclops & Dracunculiasis & & & & & & & & & & & & & $\rightarrow$ & & & & \\
\hline Ticks & Lyme divesse & & & & & & & $\omega$ & . & & & & & & & & . & \\
\hline
\end{tabular}

Single astarisks means somowhat offective and doublo atoricks means vary offoctive

"Small dems: adverse offect and largo dame: good effoct.

\section{Lyme disease cycle and transmission}

Although the disease was first identified in 1883 (Burgdorfer, 1993) it was 1981 before the spirochete Borrelia burgdorferi (a corkscrew shaped bacterium) was confirmed as the cause of Lyme disease (Burgdorfer, 1993). In 1982, the year that Lyme dis ease surveillance began in the US, there were 491 cases reported. In 1999 there were more than 16,000 cases reported in the United States.

The transmission of Lyme disease is restricted to ticks of the Ixodes ricinus complex (Dennis, 1993). In eastern North America, the tick vector is the black-legged tick (Ixodes scapularis formerly Ixodes dammini), the range of which is expanding (Anderson et al., 1990; Barker et al., 1992).

The spirochetes that cause Lyme disease "do not live in water, soil, or plants and are not transmitted by aerosols or fecal contamination" (Barbour and Fish, 1993, p. 1612) and humans are only accidental hosts. When an infected tick feeds on a host animal, the bacteria migrate to the salivary glands (Anderson and Magnarelli, 1993), from where they are transmitted to the host.

Black-legged ticks have a three-host life cycle (Fig. 2) that is approximately 2 years in duration and incorporates three blood meals, one for each of the larval, nymphal, and adult stages (Sonenshine, 1991). Ticks transmit the spirochetes through their saliva while feeding and the likelihood of transmission increases with feeding duration (Mather, 1993). Infected ticks must remain attached for at least $48 \mathrm{~h}$ to transmit the spirochete (after which time about $50 \%$ of ticks transmit the infection), with almost $100 \%$ of infected ticks transmitting the infection to their host after $72 \mathrm{~h}$ of attachment (Mather, 1993).

Peak activities of the different life stages of the tick occur at different times of the year. Larvae hatch predominantly during mid-summer (July to early August), at which time they begin host-seeking (Anderson and Magnarelli, 1993). Larvae are tiny (about the same size as the period at the end of this sentence) and actively disperse no more than about 3m from where they hatch (Daniels and Fish, 1990; Stafford, 1992). They feed predominantly on small mammals, the white-footed mouse (Peromyscus leucopus) being one of their major hosts (Godsey et al., 1987; Anderson, 1988; Mather et al., 1989). Other hosts for the larvae include chipmunks, shrews, squirrels, voles, and ground-dwelling birds, larvae having been reported to feed upon at least 27 species of mammals, and 36 species of birds (Anderson, 1988). Once fed, the larvae drop to the ground and moult (either immediately or the following spring), emerging as nymphs which begin host-seeking in the late spring and early summer (late May to early July) (Anderson and Magnarelli, 1993). Nymphs are approximately the size of a poppy seed (Ostfeld, 1997) and feed upon as many types of hosts as do larvae. Nymphs have been reported on at least 25 mammalian and 44 avian species (Anderson, 1988) with white-footed mice again being the major host at this stage. Following their blood meal, nymphs drop to the ground and moult into adults (Anderson and Magnarelli, 1993). 


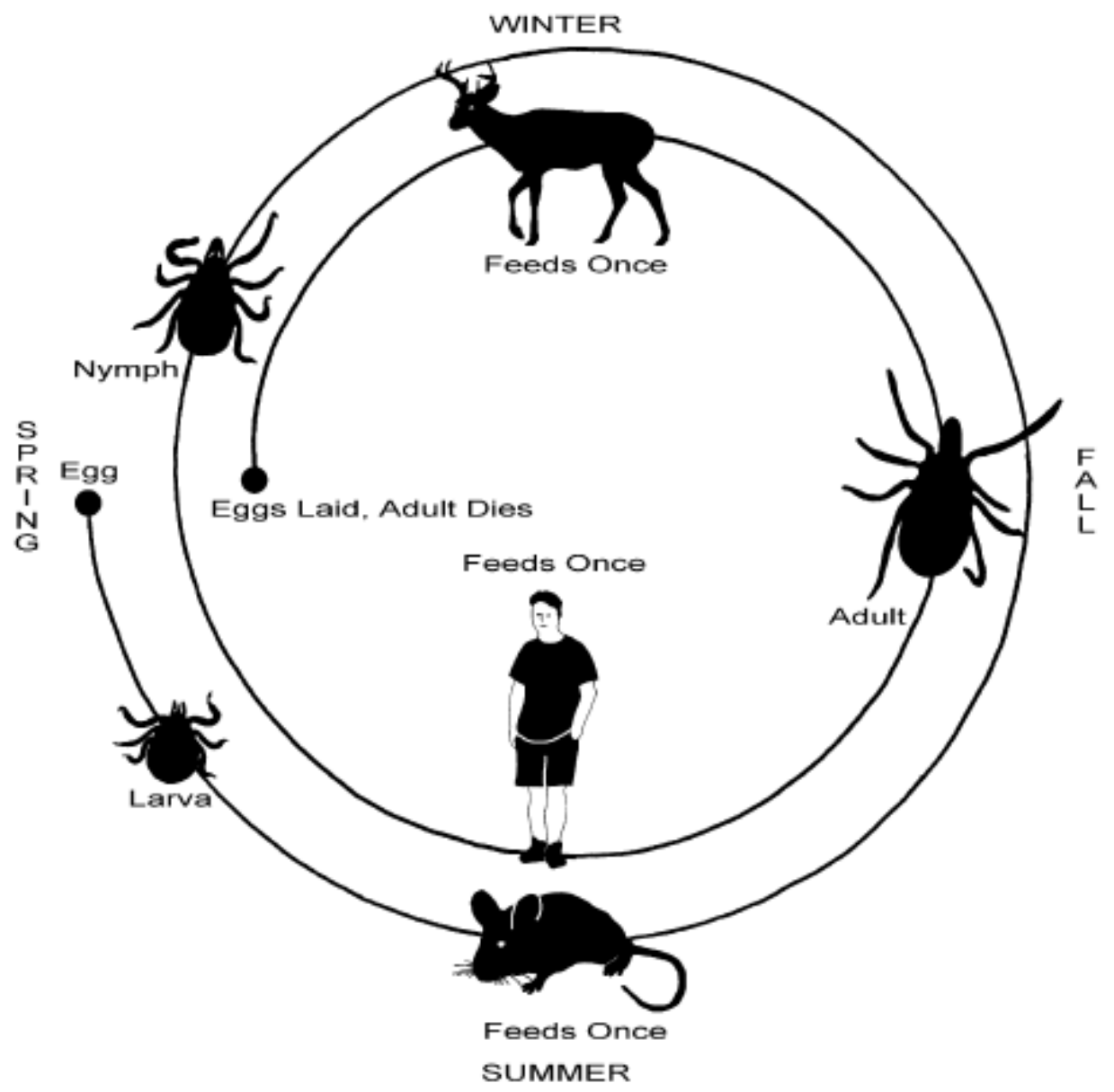

Fig. 2. The life cycle of the black-legged tick (Irodes scapularis) (after Spielman et al., 1985).

Adult ticks seek hosts from mid-October to mid-November, on warm days throughout winter, and again in early spring of the following year. Adults feed on a much smaller variety of hosts than do the larval and nymphal stages. Adults are known to feed on only about 13 different species of mammals (Anderson, 1988). The major host for adult ticks throughout much of their range is the white-tailed deer (Odocoileus virginianus), although other medium to large-sized mammals are also parasitized (Piesman et al., 1979; Anderson and Magnarelli, 1980; Wilson and Spielman, 1985). Once feeding is complete, female ticks drop to the ground, and, in May, lay a mass of hundreds to thousands of eggs, which hatch into larvae later in the season (Ostfeld, 1997).

The prevalence of infection in ticks apparently varies widely among populations in different geographical locations, based on the wide range of reported percentages, but one study (Ostfeld, 1997) reported that $25-35 \%$ of nymphs, and $50-75 \%$ of adult ticks in Lyme disease endemic areas were infected with $B$. burgdorferi.

One bite from an infected tick is sufficient to infect the host (Mather, 1993). The nymphal stage is most commonly implicated in the infection of humans. This is likely because nymphs are much smaller than adults and are more likely to be overlooked. Also, the nymphal life stage is most active during the peak season of human outdoor activity (May to June). Transovarial transmission of the spirochete (from an infected mother to her offspring) is quite low (less than 1\%), so few larval ticks are infected. Adult ticks are most active during the fall and winter, when humans are less likely to encounter them. Most management strategies and disease-risk forecasting measures target the nymphal stage of the tick. 


\subsection{The ecology of Lyme disease}

The major hosts for the Lyme disease vector are white-tailed deer (adult ticks) and white-footed mice (nymphal ticks). Because of the fact that black-legged ticks do not actively disperse more than a few metres in any life stage, their habitat associations and dispersal patterns are predominantly determined by those of the main hosts. Therefore, black-legged ticks and Lyme disease are typically encountered in areas that provide habitat supporting populations of white-tailed deer and white-footed mice.

Tick-infested deer have been shown by researchers using GIS to be associated with deciduous woodland, and with the sandy soil found along river courses (Kitron et al., 1991). Similarly, residence in close proximity to deciduous woodlands has been demonstrated to be highly correlated with the contraction of Lyme disease in humans (Glass et al., 1992). The Lyme disease vector I. scapularis and its hosts are known to inhabit primarily forested areas, with the two most important host species preferring edge habitat and thriving in disturbed landscapes (Frank et al., 1998).

These findings indicate that the reforested landscape characterizing much of the area currently affected by Lyme disease is the major underlying factor contributing to the disease's emergence. Early explorers and colonists in the northeastern part of what is now the United States reported heavy tick infestations and an abundance of deer in the native forests, conditions favouring the enzootic transmission of the Lyme disease spirochete (Anderson, 1988; Barbour and Fish, 1993). In fact, museum deer tick specimens collected from Long Island have been shown to contain spirochetal DNA fragments (Spielman et al., 1993). By the 1800s, with the clearance of vast tracts of land for agricultural use, both the tick and deer populations had been almost totally eliminated (Anderson, 1988; Barbour and Fish, 1993; Spielman et al., 1993). It should also be noted that during the nineteenth and early 20th century, a non-life threatening disease such as Lyme disease would most likely have been obscured by the many more serious illnesses that were then facing North Americans (Barbour and Fish, 1993).

It has only been in the latter part of this century that extensive reforestation has occurred throughout eastern North America. With the migration of large-scale farming to the Midwest, and the consequent abandonment of farms throughout the northeast, much of what was once agricultural land has been left to grow wild, creating a wealth of successional woodlots (Barbour and Fish, 1993; Spielman et al., 1993). At the same time, suburban developments, often favouring wooded lots and close proximity to natural areas, have become increasingly dense throughout eastern North America. In addition, increased restrictions on hunting have contributed, along with the more favourable environmental conditions created by changes in land use, to a resurgence in the deer population (Barbour and Fish, 1993). Deer populations are now thought to be greater than ever before (Spielman et al., 1993). In 1900, there were approximately 500,000 deer in North America. Today, there are estimated to be more than 30,000,000 (American Lyme Disease Foundation, 1998).

The mixture of open space, isolated woodlots, and dense forests that has been created through residential zoning laws and suburban development in the northeast of the United States has created a patchwork of habitat types that is ideal for the survival of the white-tailed deer (Spielman et al., 1993). In addition, such circumstances have resulted in far greater contact between humans and deer (and consequently their ticks) than ever before. According to Amerasinghe et al. (1993), the pattern of land use that has emerged in North America over the last half century "has resulted in a mosaic of woodland, edge vegetation, and home gardens that appear to have provided an ideal habitat for I. dammini and its zoonotic hosts" (p. 862).

\subsection{Tick habitat (landscape characteristics favouring ticks)}

Black-legged ticks are extremely sensitive to desiccation (Needham and Teel, 1991), apparently unable to survive longer than $48 \mathrm{~h}$ at less than $80 \%$ relative humidity (Adler et al., 1992). For this reason, they are restricted to moist habitats with a minimum of direct sunlight. They are primarily associated with the deciduous forests of temperate latitudes (Ostfeld, 1997) and are most often found in maple and oak habitats (Ostfeld et al., 1995). Several studies have reported that black-legged ticks of all life stages are 
consistently found to be most abundant in wooded areas (Ginsberg and Ewing, 1989; Lane et al., 1991; Maupin et al., 1991; Adler et al., 1992; Carroll et al., 1992; Stafford and Magnarelli, 1993; Duffy et al., 1994; Ostfeld et al., 1995; Frank et al., 1998; Schmidtmann et al., 1998). However, they are also found in a variety of other habitats throughout their range.

Ginsberg and Ewing (1989) reported adult ticks to be most commonly found in high shrub habitats in spring and in the woods in fall. Nymphs were most common in woods where they were almost exclusively found in forest litter, but were also found in almost every other habitat sampled. Tick abundance in residential properties in New York state was found to be correlated with property size (Maupin et al., 1991). Properties larger than 0.5 acres were more likely to contain woodlots, and as a result greater numbers of ticks. Ticks were less abundant in lawns and ornamental plantings regardless of the size of the property. The number of larval ticks on Great Island, Massachusetts, was found to be related strongly to the density of woody vegetation, and negatively to the density of herbaceous vegetation (Adler et al., 1992). The number of white-tailed deer on the island was experimentally reduced after which the number of ticks was also substantially reduced.

Ticks were found to be five times more abundant on lawns adjacent to woods than on lawns adjacent to other lawns (Carroll et al., 1992), and the relative abundance of nymphal ticks decreased with distance from the edge of the woods. Ticks found in the lawn in a residential neighbourhood were just as likely to harbour the Lyme disease bacterium as were ticks found in the woods. Stafford and Magnarelli (1993) reported that the majority of ticks that they recovered from lawns were within $1 \mathrm{~m}$ of the lawn edge, while most of the ticks found in wooded areas were more than $3 \mathrm{~m}$ from any defined edge.

In southeastern New York state, ticks were found to be most common in maple and oak habitats, and least common in hayfield habitat type (Ostfeld et al., 1995), while ticks in Wisconsin were found to be most often associated with wooded areas, remote pastures, and ungrazed woodlands, and to be uncommon in farmhouse yards and practically non-existent in agricultural fields (Schmidtmann et al., 1998).

These studies on tick habitat provide valuable insight into where and when people are most likely to encounter infected ticks in the landscape. This information should inform planning and design so that appropriate land use decisions can be made, but in its present form is difficult to use. The following process should facilitate that use.

\section{Considering Lyme disease in landscape decisions}

Literature on the ecology of Lyme disease and on the landscape planning and design process was used as a basis for the development of a three-part process for considering Lyme disease transmission in landscape development: a decision tree; a landscape features checklist; and design guidelines. Considered together, all three elements comprise a framework for the incorporation of Lyme disease prevention measures into the landscape planning and design process.

\subsection{Decision tree}

Basic categories of information essential to the determination of infectious disease transmission risk were identified from the literature and transformed into questions for the decision tree (Fig. 3). The decision tree process was designed to fit within the 'inventory and analysis' phase of the landscape planning and design process. The decision tree outlines the key decisions that must be made to determine the level of risk posed by Lyme disease for a specific project, be it at the planning, design, or landscape management stage. The decision tree also provides guidance for the level of disease prevention that is appropriate, given the determined level of risk as well as factors such as level of use and site location. The decision tree itself is generic and can be used for other diseases, provided a specific landscape features checklist is developed. 


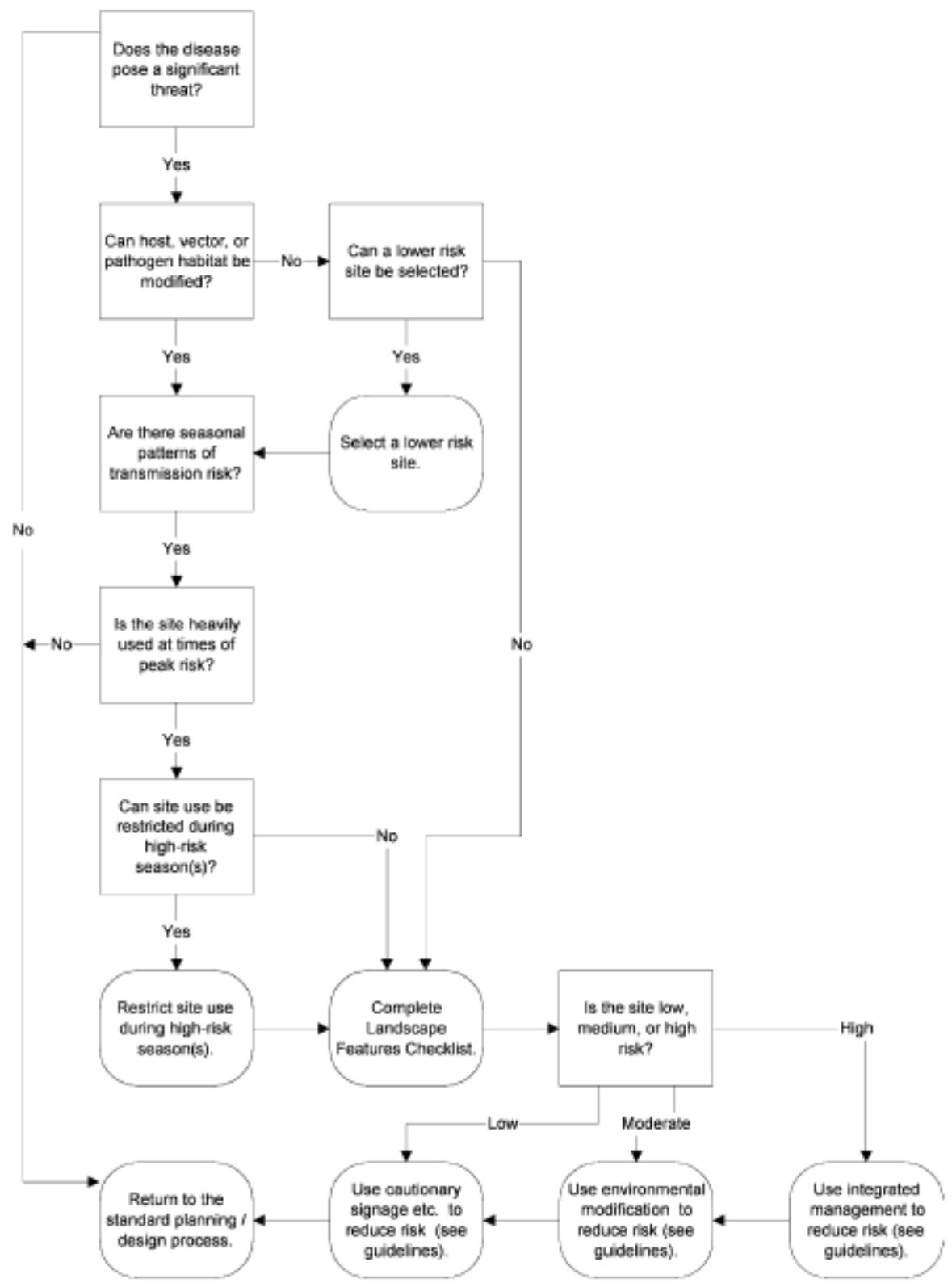

Fig. 3. A decision tree framework for considering infectious diseases in planning, design, and management decisions.

\subsection{Landscape features checklist}

A landscape features checklist was developed specifically for Lyme disease. Landscape features that have been found in previous studies to be associated with Lyme disease transmission risk (Table 3) were identified and incorporated into the checklist.

The checklist (Table 4) is intended to be utilized during the site inventory and analysis stage of the landscape planning and design process. The checklist involves the collection of detailed site-specific information, hence being more applicable to the site design process than to the planning process. The checklist represents a summary of landscape features that have been demonstrated to be associated with the risk of Lyme disease transmission. The list is only as complete as current research in the field allows, and should be updated regularly as new information is discovered about the ecology of Lyme disease. 
Table 3

List of references for landscape fearures checklist and design guidelines

\begin{tabular}{|c|c|}
\hline & Reference \\
\hline \multicolumn{2}{|l|}{ Landscape features associated with increased risk } \\
\hline Forested habitat & $\begin{array}{l}\text { Schmidtmann et al. (1998); Lane et al (1991); Lindsay } \\
\text { et al. (1997); Stafford and Magnarelli (1993) }\end{array}$ \\
\hline Greater than 0.5 acres & Maupin et al. (1991) \\
\hline Predominately maple and oak & Ostfeld et al. (1995) \\
\hline Close to forested area & Maupin et al. (1991); Stafford and Maguarelli (1993) \\
\hline High tree canopy & Lane et al (1991) \\
\hline Heavy mast prochuction 2 years previously & Ostfeld (1997) \\
\hline Dense vegetative cover in $0-1 \mathrm{~m}$ layer & Drickamer $(1990)$ \\
\hline Small herbaceous patches & Ostfeld et al. (1995) \\
\hline High proportion of edge & Stafford and Magnarelli (1993); Lane et al. (1991) \\
\hline Dense brush and woody shrubs $\sim 1 \mathrm{~m}$ high & Maupin et al. (1991) \\
\hline Dense brush & Lane et al (1991); Stafford and Magnarelli (1993) \\
\hline High proportion of lawn $1 \mathrm{~m}$ or less from edge & Stafford and Magnarelli (1993) \\
\hline High proportion of lawn $0-3 \mathrm{~m}$ from woods & Stafford and Magnarelli (1993) \\
\hline High proportion of lawn $0-3 \mathrm{~m}$ from stone walls & Stafford and Magnarelli (1993) \\
\hline Presence of white-tailed deer & Wilson et al. (1990); Deblinger et al. (1993) \\
\hline Presence of white-footed mice & Mather et al. (1989) \\
\hline Dense vegetative cover between 0 and $7.6 \mathrm{~cm}$ & M'Closkey and Lajoie (1975) \\
\hline Presence of ground foraging birds & Battaly and Fish (1993) \\
\hline Thick ground cover/moist humus at ground level & Maupin et al. (1991) \\
\hline Heavy leaf litter at ground surface & Stafford and Magnarelli (1993); Maupin et al. (1991) \\
\hline Heavy shade & Maupin et al. (1991) \\
\hline Property 1 acre or larger & Lane et al (1991) \\
\hline \multicolumn{2}{|l|}{ Landscape features associated with decreased risk } \\
\hline Average temperature over 27 for two weeks or more & Shih et al. (1995) \\
\hline Presence of stone walls & Stafford and Magnarelli (1993) \\
\hline Agricultural land & Lane et al (1991) \\
\hline Open space/grassland habitat & Lane et al (1991) \\
\hline Pasture with little understory or leaf litter & Schmidtmann et al. (1998) \\
\hline Grass pasture/lawn & Schmidtmann et al. (1998); Maupin et al (1991) \\
\hline Dense natural grassland & MCloskey and Lajoie (1975) \\
\hline Omamental plantings & Maupin et al. (1991) \\
\hline Dune habitat & Lindsay et al. (1997) \\
\hline
\end{tabular}

Further, the checklist should not be considered to provide a concrete determination of Lyme disease transmission risk for a specific site, but to act only as a guideline.

Those features that have consistently been shown in the literature to be associated with an increased risk of Lyme disease transmission have been judged to be high-risk factors (landscape features 1-7). Any site in a Lyme disease endemic area having at least one of these features present should be treated as high risk.

Landscape features $8-18$ represent moderate risk factors. These features have been demonstrated in the literature to have some association with Lyme disease transmission risk, although not to the same extent as the high-risk factors. Moderate risk factors might be landscape features that have not been confirmed through multiple studies, or features that have been demonstrated through multiple studies to be associated with an intermediate degree of disease transmission risk.

Landscape features 19-22 represent those features that are associated with a low risk for Lyme disease transmission, based on a preponderance of evidence in the literature. Further, any sites in endemic areas that do not contain any of the landscape features listed in the checklist may be considered of low risk. For example, such sites may consist of hard landscaping or coastal areas, landscapes that have not been demonstrated to be associated with Lyme disease transmission risk.

\subsection{Guidelines for Lyme disease}

The results of this study are a set of guidelines for those undertaking policy-making, planning, design (Table 5), and management (Table 6) in areas with endemic Lyme disease. A similar set of guidelines 
Table 4

Landscape features checklist

SITE IS HIGH RISK IF ONE OR MORE OF THE FOLLOWING IS TRUE:

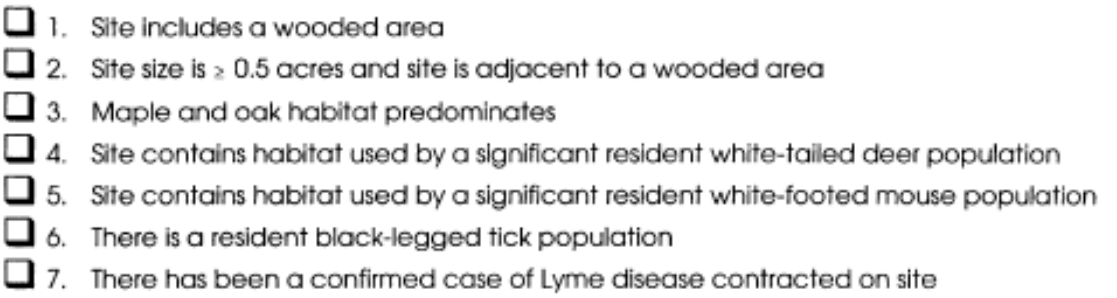

Site is moderate risk if none of the above is checked and one or more of the following is true:

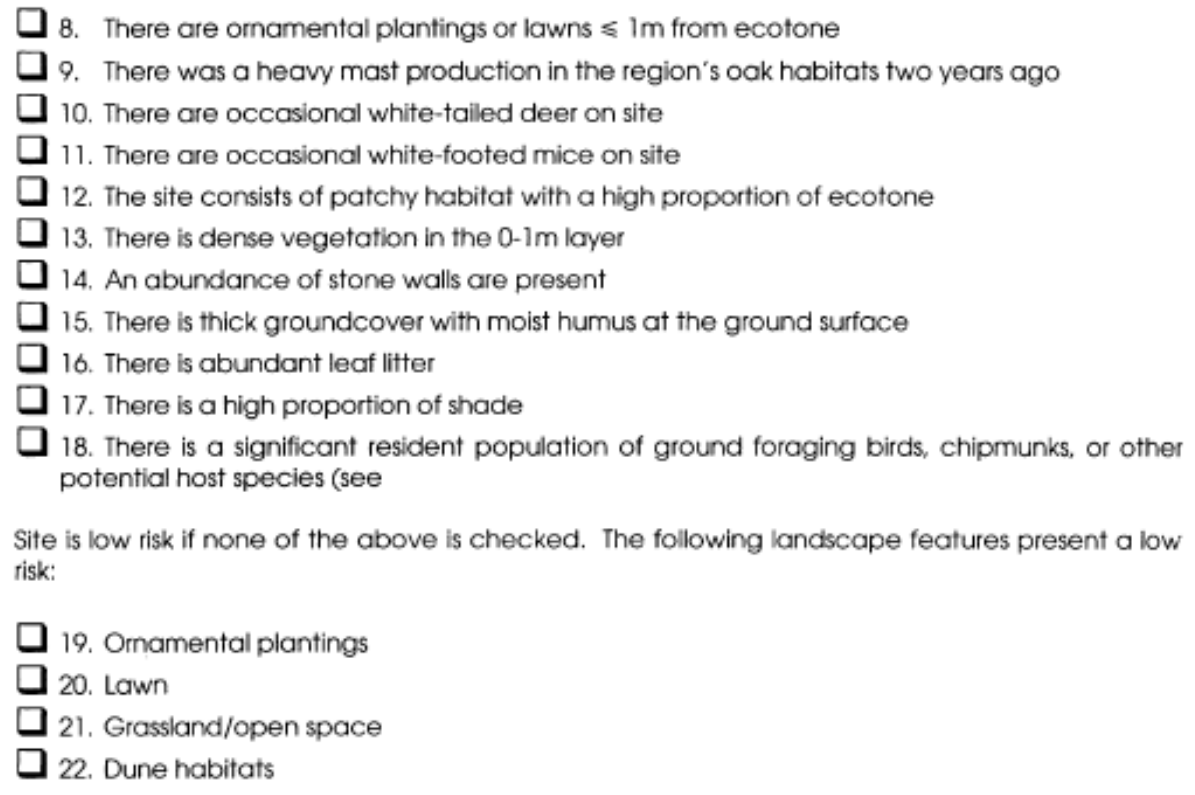

could be developed for other infectious diseases that are associated with landscape features, such as malaria or schistosomiasis.

This set of guidelines was developed from information collected through an extensive literature review on the subject of Lyme disease and its transmission. Many of the studies that were reviewed contained recommendations for the reduction of exposure to the hosts and vectors of Lyme disease. These recommendations were compiled and used to develop concrete guidelines for landscape planning, design, and management. The recommendations for the management of Lyme disease transmission are categorized according to the stage of the design process to which they are most relevant. For example, recommendations relating to programming, site selection, and plant species selection are incorporated into planning and design guidelines. However, recommendations relating to site maintenance and operations are incorporated into management guidelines. The guidelines are also grouped into several broad categories relating to the aspect of the environment being manipulated. This is intended to facilitate the application of the guidelines. The categories are based on the aspects of the environment for which the majority of the planning, design, and management recommendations are identified in the literature.

The planning, design, and management guidelines presented in Tables 5 and 6 can be easily integrated into the existing planning and design process. The implementation of these guidelines 
Table 5

Guidelines for planning and design that recuce the potential for infectious disease transmission in the landscape

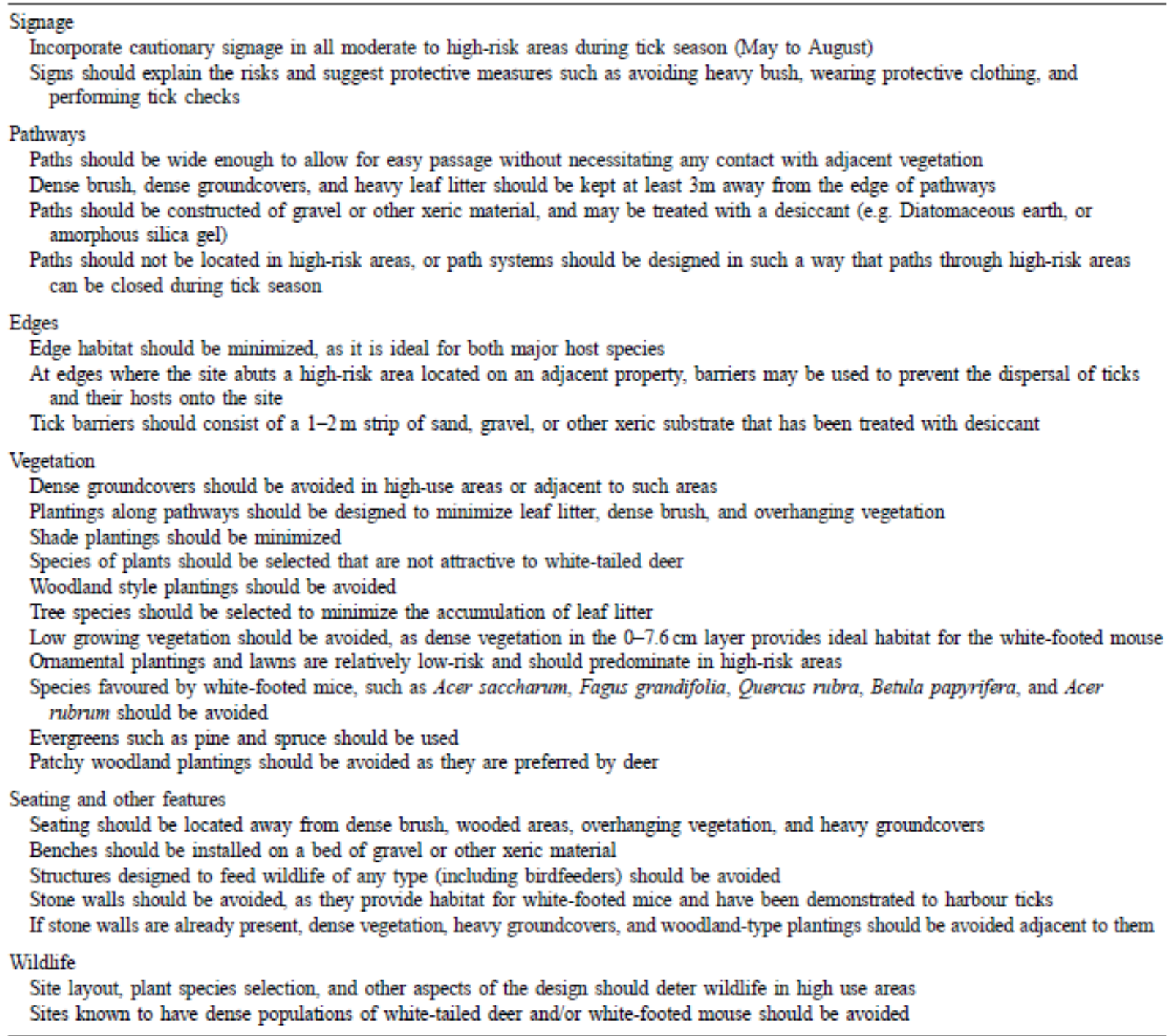

represents a possible approach to mitigation, where an unacceptable risk of Lyme disease transmission is determined to exist.

These guidelines reflect the current state of knowledge concerning the relationship between Lyme disease transmission and landscape features, and should be reviewed and altered accordingly as new research dictates. The guidelines are most thorough in the areas of design and management, as the majority of research thus far has focused on site-scale relationships. Some recent research, including that of Ostfeld et al. (1995, 1996a,b, 1997), and the work being undertaken by D. Fish and co-workers (e.g. Dister et al., 1997), involves the examination of larger-scale associations between landscape and Lyme disease transmission and may soon provide additional direction for policy-makers and planners. 
Table 6

Guidelines for management that reduce the potential for infectious disease transmission in the landscape

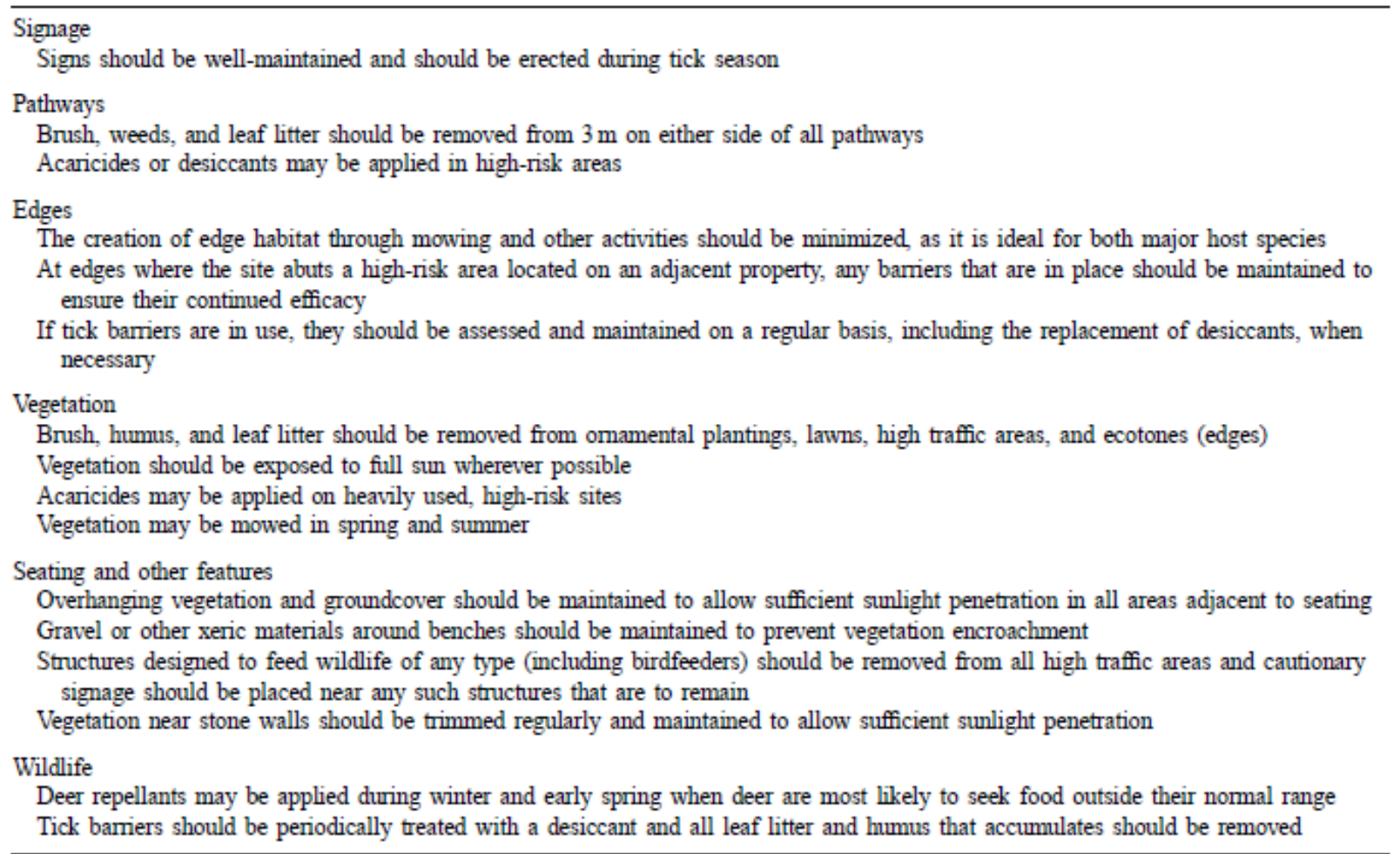

\section{Recommendations for future research}

The growing body of knowledge related to environment and health has the potential to be integrated into Geographic Information Systems and Remote Sensing Systems for use in planning and design. Models should continue to be developed that will provide simulations of the effects of various landscape planning, design, and management recommendations on the potential for disease transmission.

The success and appropriateness of the framework, features, and guidelines provided in this study should be tested. Landscape development in a Lyme disease endemic area that follows the recommendations of this study could later be tested through post-occupancy evaluation to determine effectiveness.

Research into the links between landscape and other diseases is desperately needed. Vast numbers of people continue to die every year from diseases such as malaria and schistosomiasis. Research on the links between these diseases and the landscape is critical and could have an immediate and positive impact.

\section{Conclusion}

Infectious diseases pose an increasing threat to human populations. There is a very strong connection between the organisms that cause these diseases, and the environment that the pathogens are increasingly sharing with people. Both human population growth and the expansion of human habitation areas are placing greater numbers of people into contact with pathogens. Landscape planning, design, and management can help to counteract this effect through careful and appropriate land use decisions. The information generated through this study is a first step towards the realization of this goal. 


\section{References}

Adler, G.H., Telford III, S.R., Wilson, M.L., Spielman, A., 1992. Vegetation structure influences the burden of immature Ixodes dammini on its main host, Peromyscus leucopus. Parasitology 105, 105110.

Amerasinghe, F.P., Breisch, N.L., Neidhardt, K., Scott, T.W., 1993. Increasing density and Borrelia burgdorferi infection of deer-infesting Ixodes dammini (Acari: Ixodidae) in Maryland. J. Med. Entomol. 30 (5), 858-864.

American Lyme Disease Foundation, 1998. Other tick-borne diseases. http://www.aldf.com/ttemplates/MajorTick.cfm, 20 May, 1999.

Anderson, J.F., 1988. Mammalian and avian reservoirs for Borrelia burgdorferi. Ann. N.Y. Acad. Sci. $159,180-191$.

Anderson, J.F., Magnarelli, L.A., 1980. Vertebrate host relationships and distribution of ixodid ticks (Acari: Ixodidae) in Connecticut, USA. J. Med. Entomol. 17, 314-323.

Anderson, J.F., Magnarelli, L.A., 1993. Natural history of Borrelia burgdorferi in vectors and vertebrate hosts. In: H.S. Ginsberg (Ed.), Ecology and Environmental Management of Lyme Disease. Rutgers University Press, New Brunswick, NJ, pp. 11-24.

Anderson, J.F., Durray, P.H., Magnarelli, L.A., 1990. Borrelia burgdorferi and Ixodes dammini prevalent in the greater Philadelphia area. J. Infect. Dis. 161, 811-812.

Armelagos, G.J., 1998. The Viral Superhighway. The Sciences. January/February, pp. 24-29.

Barbour, A.G., Fish, D., 1993. The Biological and Social Phenomenon of Lyme Disease. Science 260, 1610-1616.

Barker, I.K., Surgeoner, G.A., Artsob, H., McEwen, S.A., Elliot, L.A., Campbell, G.D., Robinson, J.T., 1992. Distribution of the Lyme disease vector Ixodes dammini (Acari: Ixodidae) and isolation of Borrelia burgdorferi in Ontario, Canada. J. Med. Entomol. 29 (6), 1011-1022.

Battaly, G.R., Fish, D., 1993. Relative importance of bird species as hosts for immature Ixodes dammini (Acari: Ixodidae) in a suburban residential landscape of southern New York state. J. Med. Entomol. 30 (4), 740-747.

Bridges, E.M., 1989. Toxic metals in amenity soil. Soil Use Manage. 5 (3), 91-100.

Burgdorfer, W., 1993. Discovery of Borrelia burgdorferi. In: Coyle, P. (Ed.), Lyme Disease. Mosby Year Book Inc., St. Louis, pp. 3-7.

Carroll, M.C., Ginsberg, H.S., Hyland, K.E., Hu, R., 1992. Distribution of Ixodes dammini (Acari: Ixodidae) in residential lawns of Prudence Island, Rhode Island. J. Med. Entomol. 29 (6), 1052-1055.

Colwell, R.R., 1996. Global climate and infectious disease: the cholera paradigm. Science 274, 2025031.

Daniels, T.J., Fish, D., 1990. Spatial distribution and dispersal of unfed larval Ixodes dammini (Acari: Ixodidae) in southern New York. Environ. Entomol. 19 (4), 1029-1033.

Deblinger, R.D., Wilson, M.L., Rimmer, D.W., Spielman, A., 1993. Reduced abundance of immature Ixodes dammini (Acari: Ixodidae) following incremental removal of deer. J. Med. Entomol. 30 (1), 144-150.

Dennis, D.T., 1993. Epidemiology. In: Coyle, P. (Ed.), Lyme Disease. Mosby Year Book Inc., St. Louis, pp. 18-26.

Dister, S.W., Fish, D., Bros, S.M., Frank, D.H., Wood, B.L., 1997. Landscape characterization of peridomestic risk for Lyme disease using satellite imagery. Am. J. Trop. Med. Hyg. 57 (6), 687-692.

Dobson, A.P., Carper, E.R., 1996. Infectious diseases and human population history. BioScience 46 (2), $115-126$.

Drickamer, L.C., 1990. Microhabitat preferences of two species of deermice Peromyscus in a northeastern United States deciduous hardwood forest. Acta Theriologica 35 (3-4), 241-252.

Dubos, R., 1965. Man Adapting. Yale University Press, New Haven, CT. 
Duffy, D.C., Clark, D.D., Campbell, S.R., Gurney, S., Perello, R., Simon, N., 1994. Landscape patterns of abundance of Ixodes scapularis (Acari: Ixodidae) on Shelter Island, New York. J. Med. Entomol. 31 (6), 875-879.

Frank, D.H., Fish, D., Moy, F.H., 1998. Landscape features associated with Lyme disease risk in a suburban residential environment. Landscape Ecol. 13, 27-36.

Gerlach-Spriggs, N., Kaufmann, R.E., Bass Warner Jr., S., 1998. Restorative Gardens: The Healing Landscape. Yale University Press, New Haven, CT.

Ginsberg, H.S., Ewing, C.P., 1989. Habitat distribution of Ixodes dammini (Acari: Ixodidae) and Lyme disease spirochetes on Fire Island, New York. J. Med. Entomol. 26 (3), 183-189.

Glass, G.E., Morgan III, J.M., Johnson, D.T., Noy, P.M., Israel, E., Schwartz, B., 1992. Infectious disease epidemiology and GIS: A case study of Lyme disease. Geographic Information Systems. November/December, pp. 65-69.

Godsey, M.S., Amundson, T.E., Burgess, E.C., Schell, W., Davis, J.P., Kaslow, R., Edelman, R., 1987. Lyme disease ecology in Wisconsin: distribution and host preferences of Ixodes dammini, and prevalence of antibody to Borrelia burgdorferi in small mammals. Am. J. Trop. Med. Hyg. 37 (1), $180-187$.

Gubler, D.J., Reiter, P., Ebi, K.L., Yap, W., Nasci, R., Patz, J.A., 2001. Climate variability and change in the United States: potential impacts on vector- and rodent-borne diseases. Environ. Health Perspect. 109 (2), 223-233.

Kitron, U., Bouseman, J.K., Jones, C.J., 1991. Use of ARC/INFO GIS to study the distribution of Lyme disease ticks in Illinois country. Prev. Vet. Med. 11, 243-248.

Lane, R.S., Piesman, J., Burgdorfer, W., 1991. Lyme borreliosis: relation of its causative agent to its vectors and hosts in North America and Europe. Ann. Rev. Entomol. 36, 587-609.

Lederberg, J., Shope, R.E., Oaks Jr., S.C. (Eds.), 1992. Emerging Infection: Microbial Threats to Health in the United States. National Academy Press, Washington, DC.

Lindsay, L.R., Barker, I.K., Surgeoner, G.A., McEwen, S.A., Campbell, G.D., 1997. Duration of Borrelia burgdorferi infectivity in white-footed mice for the tick vector Ixodes scapularis under laboratory and field conditions in Ontario. J. Wildl. Dis. 33 (4), 767-775.

Lyons, A.S., Petrucelli, R.J., II, 1987. Medicine: An Illustrated History. Harry N. Abrams Inc., New York.

Mather, T.N., 1993. The dynamics of spirochete transmission between ticks and vertebrates. In: H.S. Ginsberg (Ed.), Ecology and Environmental Management of Lyme Disease. Rutgers University Press, New Brunswick, NJ, pp. 43-60.

Mather, T.N., Wilson, M.L., Moore, S.I., Ribeiro, J.M.C., Spielman, A., 1989. Comparing the relative potential of rodents as reservoirs of the Lyme disease spirochete (Borrelia burgdorferi). Am. J. Epidemiol. 130 (1), 143-150.

Maupin, G.O., Fish, D., Zultowsky, J., Campos, E.G., Piesman, J., 1991. Landscape ecology of Lyme Disease in a residential area of Westchester County, New York. Am. J. Epidemiol. 133 (11), 11051113.

McHarg, I.L., 1969. Design with Nature. Doubleday, New York.

M'Closkey, R.T., Lajoie, D.T., 1975. Determinants of local distribution and abundance in white-footed mice. Ecology 56, 467-472.

McMichael, A.J., 1993. Planetary Overload: Global Environmental Change and the Health of the Human Species. Cambridge University Press, New York.

Meade, M.S., Florin, J.W., Gesler, W.M., 1988. Medical Geography. The Guilford Press, New York.

National Center for Infectious Diseases, 1999. Lyme disease cases reported to CDC by state health departments, 1982-1997.

Centers for Disease Control and Prevention, Atlanta, Georgia. http://www.cdc.gov/ncidod/dvbid/lyme/index.htm, 10 June 1999.

Needham, G.R., Teel, P.D., 1991. Off-host physiological ecology of Ixodid ticks. Ann. Rev. Entomol. 36, 659-681. 
Olliaro, P., Cattani, J., Wirth, D., 1996. Malaria, the submerged disease. J. Am. Med. Assoc. 275 (3), 230-233.

Ostfeld, R.S., 1997. The ecology of Lyme-disease risk. Am. Scientist 85 (4), 338-346.

Ostfeld, R.S., Cepeda, O.M., Hazler, K.R., Miller, M.C., 1995. Ecology of Lyme disease: habitat associations of ticks (Ixodes scapularis) in a rural landscape. Ecol. Appl. 5 (2), 353-361.

Ostfeld, R.S., Jones, C.G., Wolff, J.O., 1996a. Of mice and mast. BioScience 46 (5), 323-330.

Ostfeld, R.S., Miller, M.C., Hazler, K.R., 1996b. Causes and consequences of tick (Ixodes scapularis) burdens on white-footed mice (Peromyscus leucopus). J. Mammal. 77 (1), 266-273.

Piesman, J., Spielman, A., Etkind, P., Ruebush, T.K., Juranek, D.D., 1979. Role of deer in the epizootiology of Babesia microti in Massachusetts, USA. J. Med. Entomol. 15, 537-540.

Pimentel, D., Tort, M., D’Anna, L., Krawic, A., Berger, J., Rossman, J., Mugo, F., Doon, N., Shriberg, M., Howard, E., Lee, S., Talbot, J., 1998. Ecology of increasing disease. BioScience 48 (10), 817-826.

Pinner, R.W., Teutsch, S.M., Simonsen, L., Klug, L.A., Graber, J.M., Clarke, M.J., Berkelman, R.L., 1996. Trends in infectious diseases martality in the United States. J. Am. Med. Assoc. 275 (3), 189193.

Platt, A.E., 1996. Infecting ourselves: How environmental and social disruptions trigger disease. Worldwatch Paper 29. Worldwatch Institute, Washington, DC.

Real, L.A., 1996. Sustainability and the ecology of infectious disease. BioScience 46 (2), 88-97.

Schmidtmann, E.T., Schlater, J.L., Maupin, G.O., Mertins, J.W., 1998. Vegetational associations of hostseeking adult black-legged ticks Ixodes scapularis Say (Acari: Ixodidae), on dairy farms in northwestern Wisconsin. J. Dairy Sci. 81 (3), 718-721.

Shih, C.-M., Telford III, S.R., Spielman, A., 1995. Effect of ambient temperature on competence of deer ticks as hosts for Lyme disease spirochetes. J. Clin. Microbiol. 33 (4), 958-961.

Sonenshine, D.E., 1991. Biology of Ticks, vol. 1. Oxford University Press, New York.

Spielman, A., Wilson, M.L., Levine, J.F., Piesman, J., 1985. Ecology of Ixodes dammini-borne human babesiosis and Lyme disease. Ann. Rev. Entomol. 30, 439-460.

Spielman, A., Telford III, S.R., Pollack, R.J., 1993. The origins and course of the present outbreak of lyme disease. In: H.S. Ginsberg (Ed.), Ecology and Environmental Management of Lyme Disease. Rutgers University Press, New Brunswick, NJ, pp. 43-60.

Stafford, K.C., 1992. Oviposition and larval dispersal of Ixodes dammini (Acari: Ixodidae). J. Med. Entomol. 29 (1), 129-132.

Stafford III, K.C., Magnarelli, L.A., 1993. Spatial and temporal patterns of Ixodes scapularis (Acari: Ixodidae) in southeastern Connecticut. J. Med. Entomol. 30 (4), 762-771.

US Public Health Service, and Centers for Disease Control and Prevention, 1994. Addressing emerging infectious disease threats: a prevention strategy for the United States. National Center for Infectious Diseases, Atlanta.

Walsh, J.F., Molyneux, D.H., Birley, M.H., 1993. Deforestation: effects on vector-borne disease. Parasitology 106, S55-S75.

Wilson, M.L., Spielman, A., 1985. Seasonal activity of immature Ixodes dammini (Acari: Ixodidae). J. Med. Entomol. 22 (4), 408-414.

Wilson, M.L., Ducey, A.M., Litwin, T.S., Gavin, T.A., Spielman, A., 1990. Microgeographic distribution of immature Ixodes dammini ticks correlated with that of deer. Med. Vet. Entomol. 4, 151-159.

World Health Organization Expert Committee on Vector Biology and Control, 1980. Environmental management for vector control. World Health Organization, Geneva. 